\title{
KAOLIN GENESIS
}

by

Milos Kuzvart

Kaolin genesis has many aspects - some purely theoretical (the physical and chemical conditions of kaolinization in both nature and in experiments, its age and mutual interaction with organic matter), some economic (the industrial use of kaolin and the significance of kaolinized rocks for hydrogeology, engineering geology and agriculture), some social, historical and even ritual. IGCP Project 23 (Genesis of kaolins) has been concentrating its research on some of these aspects since $1971^{*}$; Project Secretary Milos Kuzvart offers not only an intriguing summary of their findings, but also fresh insight into the origin of kaolin.

\section{Origin of Term "Kaolin"}

The name "kaolin" is derived from the Chinese term "Kau-ling" meaning "High Mountains", the name for a village near King-te-ching in the Kiangsi (or Tsiansi) province of China, where kaolin was first mined in the seventh century. "Kaolin" was used in Europe in 1712 by Father d'Entrecolle, who was sent to China by the Jesuits to learn the secret of porcelain production. In 1752 Chambres refers to porcelain produced at the kaolin deposit near Kau-ling by firing equal portions of kaolin and "petuntse", which in Chinese means crushed and bricketed hydrothermally altered porphyry, consisting of quartz and muscovite (i.e. "chinastone"). Thus, the original term "kaolin", as it was understood at the birth of the European porcelain industry, most probably referred to beneficiated, or washed kaolin.

\section{What is Kaolin?}

"Kaolin is a rock characterized by a useful content of kaolin minerals" - this definition, proposed by Professor Keller (U.S.A.), was accepted at the Third Kaolin Symposium in Exeter and Rennes in 1974. It incorporates the "economic" definition of Patterson and Murray, in Lefond, (1975, p. 546): "Kaolin is a clay consisting of substantially pure kaolinite, or related clay minerals, that is naturally or can be beneficiated to be white or nearly white, will fire white or nearly white and is amenable to beneficiation by known methods to make it suitable for uses in white ware, paper, rubber, paint and similar uses".
This definition is generally accepted throughout the world with the exception of the socialist countries, where the following genetic definition is favoured: "Kaolin is an industrially useful residual white or light coloured earth formed in situ by chemical decomposition of rock-forming minerals, especially feldspars".

\section{Genesis of Kaolin}

In the kaolinization process, the principal factors are material (parent rock), energy (thermal, chemical and kinetic energy of ground and surface waters), and time. The formation of great thicknesses of white kaolin requires high contents of minerals with a low bonding energy. Phyllosilicates and feldspars, especially plagioclases are most suitable. Low content of dark minerals and of quartz in the parent rocks and its density of fractures, cataclasis, mylonization or phyllonitization are also favourable for the development of kaolin.

During the kaolinization process, thermal and chemical energies are supplied either by an extreme climate or a low temperature hydrothermal environment. Kaolinization conditions can be approximately defined by the following parameters:

(a) aqueous environment with $\mathrm{pH} 6.6$ to 4 (the acidity of the environment is determined by the presence of $\mathrm{H}_{2} \mathrm{CO}_{3}$ );

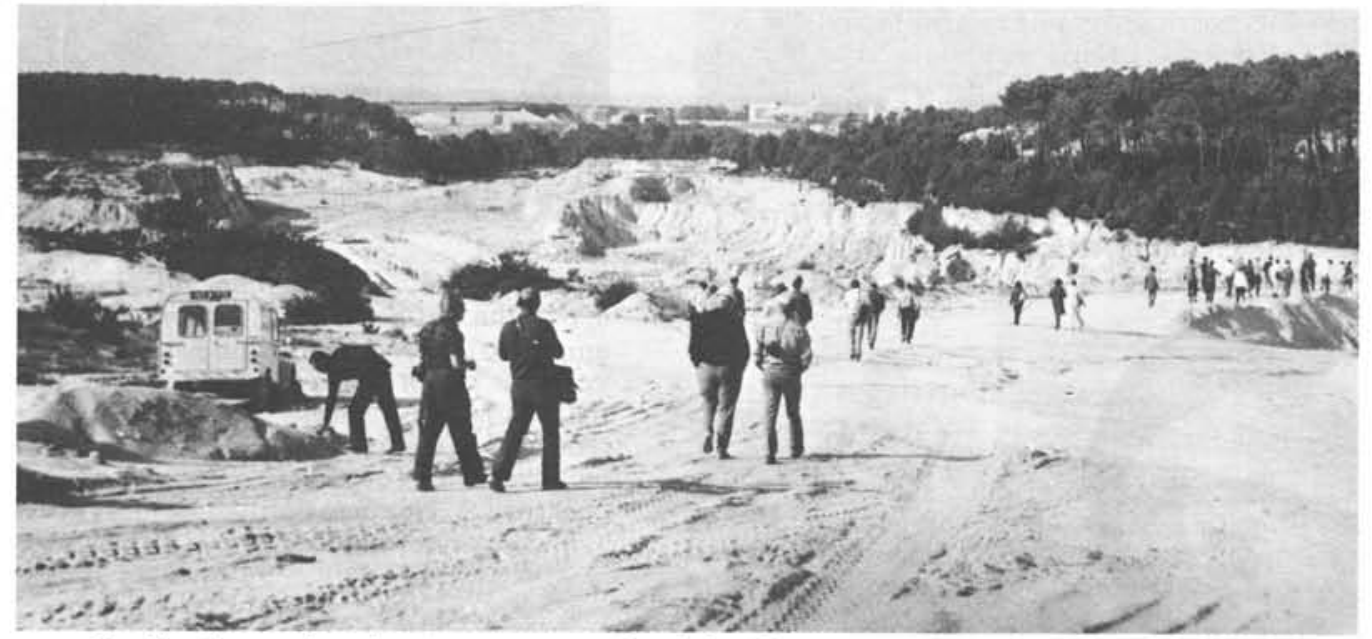

Kaolin Symposia aim to assess national kaolin resources on a worldwide scale through meetings and field investigations. Here, an excursion party heads toward the kaolin deposit "Ploemeur" during the Third International Kaolin Symposium, Brittany, 1974; the Atlantic Ocean is in the background.

\footnotetext{
* A report on the achievements of Project 23 appears in the recently published Geological Correlation, Special Issue, Paris, September 1978, p. 112-113; copies of the Special Issue are available, on request, from the IGCP Secretariat, Division of Earth Sciences, UNESCO, Place de Fontenoy, 75700 , Paris, France, or from the IUGS
Secretariat.
} 
(b) for exogenous kaolinization, the annual temperature should vary between $16^{\circ}-18^{\circ} \mathrm{C}$, while the annual precipitation should be about $1000 \mathrm{~mm}$. Such conditions are realized on the surface in the subtropical and, in particular, tropical forested zones. In savannahs, where dry and rainy seasons alternate, kaolin may originate under a lateritic crust and spotted horizon at depth;

(c) favourable geomorphological conditions are responsible for permanent removal of kaolinization products $\left(\mathrm{K}^{+}\right.$, $\mathrm{Na}^{+}, \mathrm{CA}^{++}, \mathrm{Mg}^{++}$, some $\mathrm{SiO}_{2}$ ) in hilly regions. The products of kaolinization are laterally transported by underground and surface waters;

(d) favourable conditions for removal of metals, such as: removal of iron from kaolinized melanocratic rocks takes place at a $\mathrm{pH}$ of about $3\left(\mathrm{Fe}^{3^{+}}\right)$or at higher $\mathrm{pH}$, if organic matter reducing $\mathrm{Fe}^{3+}$ to $\mathrm{Fe}^{2+}$, is present; chelation also supports removal of metals by forming cyclic bonds with aminoacids or by the influence of porphyrins derived by decomposition of chlorophyll; ion exchange causes the sorption of cations by organic gels which release the $\mathrm{H}$-ions; peptization increases the dispersion of colloid solutions and hence also the migration ability; absorption of humic matter on the surface of the oxyhydroxides of $\mathrm{Fe}, \mathrm{Mn}, \mathrm{Al}$ and others. Aluminum, iron and manganese, however, remain in the weathering crust, because complexing anions $\mathrm{OH}^{-}, \mathrm{PO}_{4}{ }^{3-}$ and $\mathrm{SiO}_{4}^{-}$cause precipitation of their organo-complexes, hence ferruginous or alumina-rich laterite, as well as secondary manganese minerals like nsutite, pyrolusite or psilomelane are frequently formed in the tropics in spite of abundant organic compounds that promote migration of metals.

The energetic conditions of kaolinization are satisfied either by long-term action of exogenous agents or by more rapid action of endogenous agents. Kaolinization may be caused by acidic epithermal waters, mostly under fumarole conditions (as, for example, in Japan and Mexico). Never- theless, the common occurrence of kaolinite and hydrothermal or even pneumatolytic minerals (such as fluorite, topaz, tourmaline, cassiterite, zinnwaldite) does not provide evidence for endogenous kaolinization. Kaolin is usually formed later, after autometamorphism or hydrothermal alteration of rocks.

The time factor plays an important role in exogenous kaolinization processes. The average annual downward rate of exogenous kaolinization is about $0.01 \mathrm{~mm}$ to $0.1 \mathrm{~mm}$ in a tectonically quiet environment. This represents a rate of 10 to $100 \mathrm{~m}$ per million years. The kaolinization process, however, decreases with depth.

The origin of kaolin as it relates to the development of the weathering crust in present-day and earlier tropical areas may be described as follows:

The senile and laterite stages of the development of tropical soil (terms used according to E.C.J. Mohr and F.A. von Baren, 1960) can be divided into five substages, depending on the occurrence and degree of concentration of ironbearing minerals in the illuvial horizon, $\mathrm{B}_{3}$ (Kuzvart, 1968). These substages (see Fig. 1) are:

I. homogenous zone of red weathered material; iron compounds are dispersed throughout the whole horizon of red weathered rock; hydrogoethite or goethite prevail;

II. weak concentration of Fe-minerals in horizon B;

III. concretions in horizon B; hematite is present together with goethite; weak development of a spotted horizon below horizon B;

IV. concretions of Fe-minerals, denudation of horizon A, compaction of horizon B at the surface by dehydration; hematite is present together with goethite; development of a spotted horizon; the crust is permeable;

$v$. the surface lateritic crust is impermeable; hematite prevails.

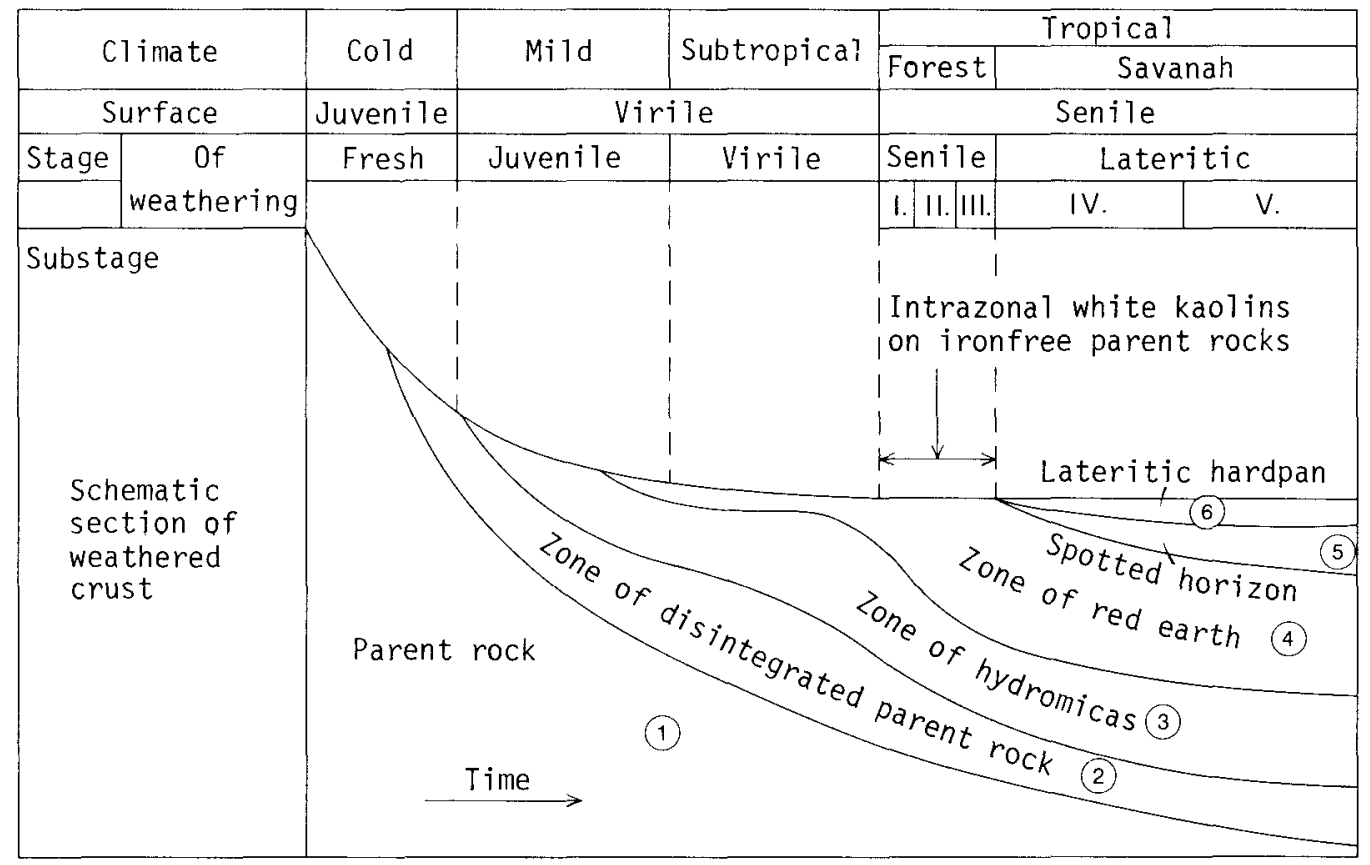

Figure 1. Influence of climate (thermal and chemical energies) and geomorphology (dynamic energy of underground and surface waters) on the development of weathering crust. Substages of development of typical weathering crust in tropical zones are: I - homogenous ruddy weathered rock; II - initial concentration of $\mathrm{Fe}$-minerals in horizon $\mathrm{B}$; III - concretions of Fe-minerals in horizon $B ; I V$ - permeable laterite crust in horizon $B ; V$-impermeable surficial laterite crust. 
In substages I and II, except for goethite, minerals of the clay fractions are represented by kaolinite (see Fig. 2). In substages III to $\mathrm{V}$, in addition to goethite and kaolinite (or halloysite - substage III), a free hydrated aluminium oxide (boehmite and/or hydrargillite) also occurs.

Substages I to III fall within the senile stage of development of tropical weathering crust. This is a typical red kaolin zone of weathering in tropical forests on senile surfaces. In this zone of red kaolin, white kaolin may occur mostly on iron-free parent rocks, such as pegmatites. This might be called "intrazonal white kaolin". A zone of hydromica and one of mechanically disintegrated parent rock usually underlie the zone of red (or intrazonal white) kaolin in deposits of exogenous kaolin.

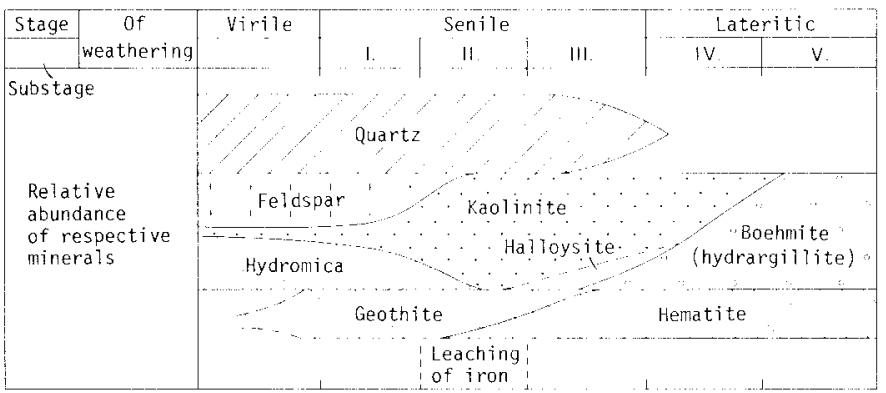

Figure 2. Proportions of residual and newly formed minerals in the uppermost (most advanced) zone of weathering crust in mild, subtropical and tropical zones.

\section{Age of Exogenous Kaolinization}

The intensity of kaolinization was not always the same throughout history. Most European kaolin deposits are of Carboniferous, Jurassic and Cretaceous-Paleogene age. These intervals apparently fall within the timespan of the formation of coal and follow the great orogenies. It can be expected that a great amount of $\mathrm{CO}_{2}$ escaped into the atmosphere, due to volcanic activity during these orogenies, was dissolved in rain water, and so, accelerated the kaolinization process. Plants also influenced kaolinization through removal of iron.

At present, the common occurrence of luxuriant growth in tropical primeval forests reduces the amount of $\mathrm{CO}_{2}$ available from the atmosphere. This undoubtedly is a factor in the decreased rate of kaolinization (and also lateritization) occuring today.

\section{Dressing of Kaolin}

Kaolin may be separated initially by washing or airflotation, followed if necessary by flotation, selective flocculation and magnetic separation. The wet process allows the removal of much of the ferruginous compounds after fractionation of the slurry. Fine fractions are leached after the addition of sulfuric acid to a pH of about 3. A strong reducing agent such as hydrosulfite is then added, and the iron reacts and forms soluble sulfate which is removed during the dewatering step (Patterson and Murray, in Lefond, 1975). Another method of bleaching is the binding of iron into colourless organo-complexes.

\section{Technical Aspects}

Kaolinized rocks are less permeable than fresh ones because their fractures, so important to the movement of underground water, are sealed by the clay minerals. This is important in hydrogeological investigation of aquifers or in prospecting for oil-bearing beds, as well as in engineering geological considerations. After heavy rains, for example, a slow creeping movement may start along the contact surface of the kaolinized rock with its waterbearing overburden, giving rise to a landslide.

\section{Pedological and Agricultural Aspects}

Kaolinite-rich soils (kaolisols) form in acid tropical soils on wet or poorly drained sites by leaching and oxidation of feldspathic rocks. Iron moves relatively easily and accumulates at the soil water table as concretions, which may later form thin lenses and masses capable of hardening on dehydration, especially after the overburden is eroded and the iron soil-horizon appears on the surface forming a laterite hardpan. Silica is only partially removed; thorough removal of silica results in the formation of bauxite minerals. At an early stage of development of the weathering profile in areas with more than $2 \mathrm{~m}$ of annual precipitation, the base content ( $\mathrm{Na}, \mathrm{K}$ and $\mathrm{Ca}, \mathrm{Mg}$ ) and sulphur, which are necessary for the production of protein, are sufficient for the nutrition of vegetation. With time, the mantle deepens, the acid front moves to depth and plants cease to extract bases. Bauxite minerals may form from kaolinite with a laterite hardpan on the surface.

Laterite is extremely difficult to cultivate as the hardpan is mostly barren. Thin iron crusts form within 30 to 60 years in West Africa after bush clearing or a forest fire. These situations are serious threats to agriculture. Tropical soils low in plant nutrients and in ion exchange capacity are apt to suffer from protein hunger. The intense chemical leaching of soils, which produced malnutrition amongst the inhabitants of the tropical belt, might be the cause of some of the poor health and lagging cultural development in some areas. These are the only parts of our planet's surface that have never produced civilization.

\section{Social and Economic Aspects}

The level of production and consumption of kaolin is an indication of the cultural and technological standards in any given country (see Table I). More kaolin means more porcelain, paper and books, wall-tiles and better housing, rubber for tires, refractories for metallurgy, mineral wool for insulation, leading to lower energy losses.

Table 1

\begin{tabular}{|c|c|c|c|}
\hline \multirow[b]{2}{*}{ Country } & \multicolumn{3}{|c|}{$\begin{array}{c}\text { Some of the major producers and importers of } \\
\text { kaolin (based on } 1972 \text { figures). }\end{array}$} \\
\hline & $\begin{array}{l}\text { Production } \\
\text { (in thousands } \\
\text { of metric tons) }\end{array}$ & Country & $\begin{array}{c}\text { Imports } \\
\text { (in thousands } \\
\text { of metric tons) }\end{array}$ \\
\hline $\begin{array}{l}\text { U.S.A. } \\
\text { U.K. } \\
\text { U.S.S.R. } \\
\text { France } \\
\text { Spain } \\
\text { C.S.S.R. } \\
\text { F.R.G. }\end{array}$ & $\begin{array}{r}4,823 \\
3,005 \\
2,000 \\
525 \\
513 \\
422 \\
417\end{array}$ & $\begin{array}{l}\text { Canada } \\
\text { Sweden } \\
\text { Libya } \\
\text { Denmark } \\
\text { Kuwait }\end{array}$ & $\begin{array}{r}324 \\
164 \\
155 \\
62 \\
9\end{array}$ \\
\hline
\end{tabular}

Ritual Aspects

The fetishist Akan tribes in southern Ghana (West Africa) used white clay in their nuptial ceremonies and this provides a colourful example of kaolin use in rituals. If the young husband was satisfied with his wife's virtue, he showered her with pulverized white clay on the morning of the wedding night and sent her with her unwedded girlfriends into town. This white clay was mostly clay substance of residual kaolin separated from course grains by decantation in a calabash véssel. 


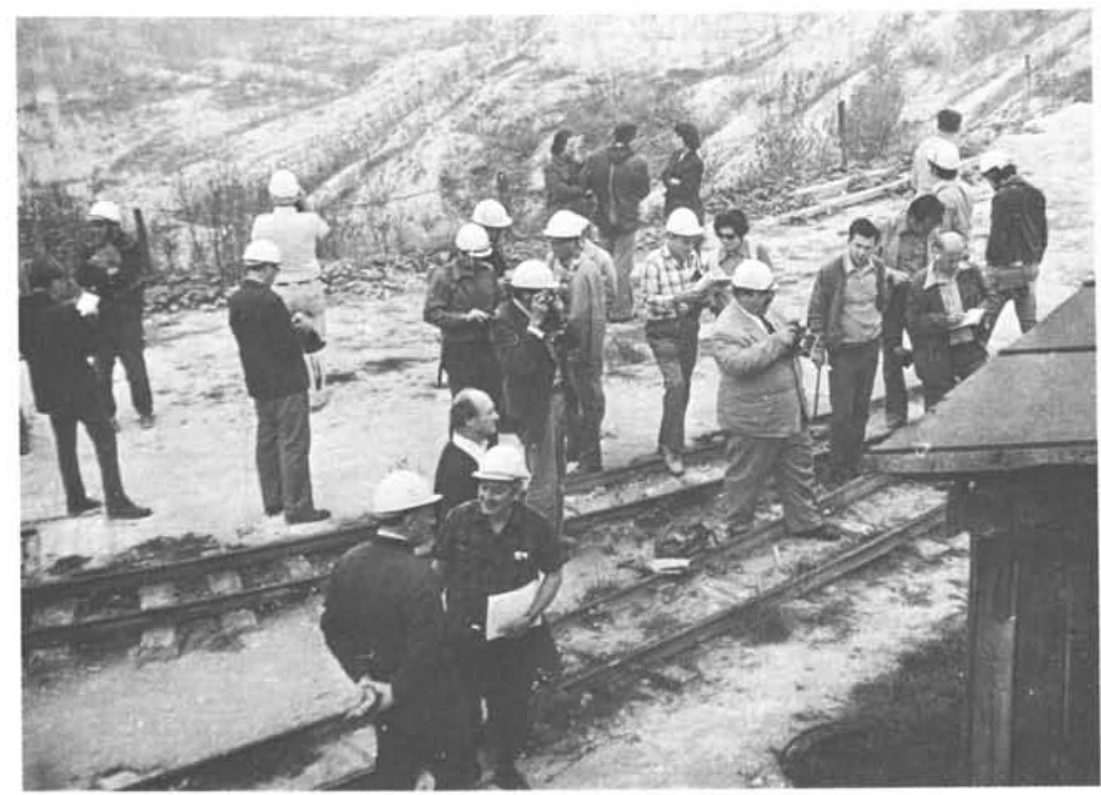

In 1975 the Fifth International Kaolin Symposium was held in the German Democratic Republic. Foreground (left to right and immediately behind): Academician Chukhrov (U.S.S.R.), Prof. Storr (G.D.R.) Dr. Bardossy (Hungary).

\section{Future Prospects}

It is estimated that there are currently reserves of 12 billion tons of kaolin in the world. The predicted annual growth of world demand for kaolin between 1973 and 2000 is 2.3\%. Thus, if the demand for kaolin in the U.S.A. in 1973 was 4.8 million tons, in 2000 it would be 20 million tons, or twice as much as the global production of 1965. The leading consumer of kaolin continues to be the paper industry (approximately half the magazines published with colour pictures now contain about $30 \%$ kaolin), while rubber, paint, ceramics, refractories and other industries follow close behind.

Paper will account for half of the demand for kaolin in the year 2000. High quality and thinner paper will probably be used to counteract rising postal rates, so that kaolin will be needed even more to maintain the opacity of this paper.

\section{References}

Keller W.D., 1955, Principles of chemical weathering: Columbia, Missouri, Lucas Brothers, 88 p.

Kuzvart M., 1968, Notes on prospecting for kaolin and clay deposits in humid tropics: Acta Univ. Carolinae, Geol. 1-2, Prague, p. 21-28.

Lefond S.J., (ed.), 1975, Industrial minerals and rocks (nonmetallics other than fuels), 4th edition: New York, Amer. Inst. of Mining, Metallurgical and Petroleum Engineers, $1360 \mathrm{p}$.

Mohr E.C. and van Baren F.A., 1960, Tropical soils, 2nd edition: The Hague, W. Van Hoeve, 498 p.

Mineral Facts and Problems, 1975 Bicentennial edition: Washington D.C., Bureau of Mines, 1259 p.

Minerals Yearbook 1973, Vol. III: Washington D.C., Bureau of Mines, $1193 \mathrm{p}$.

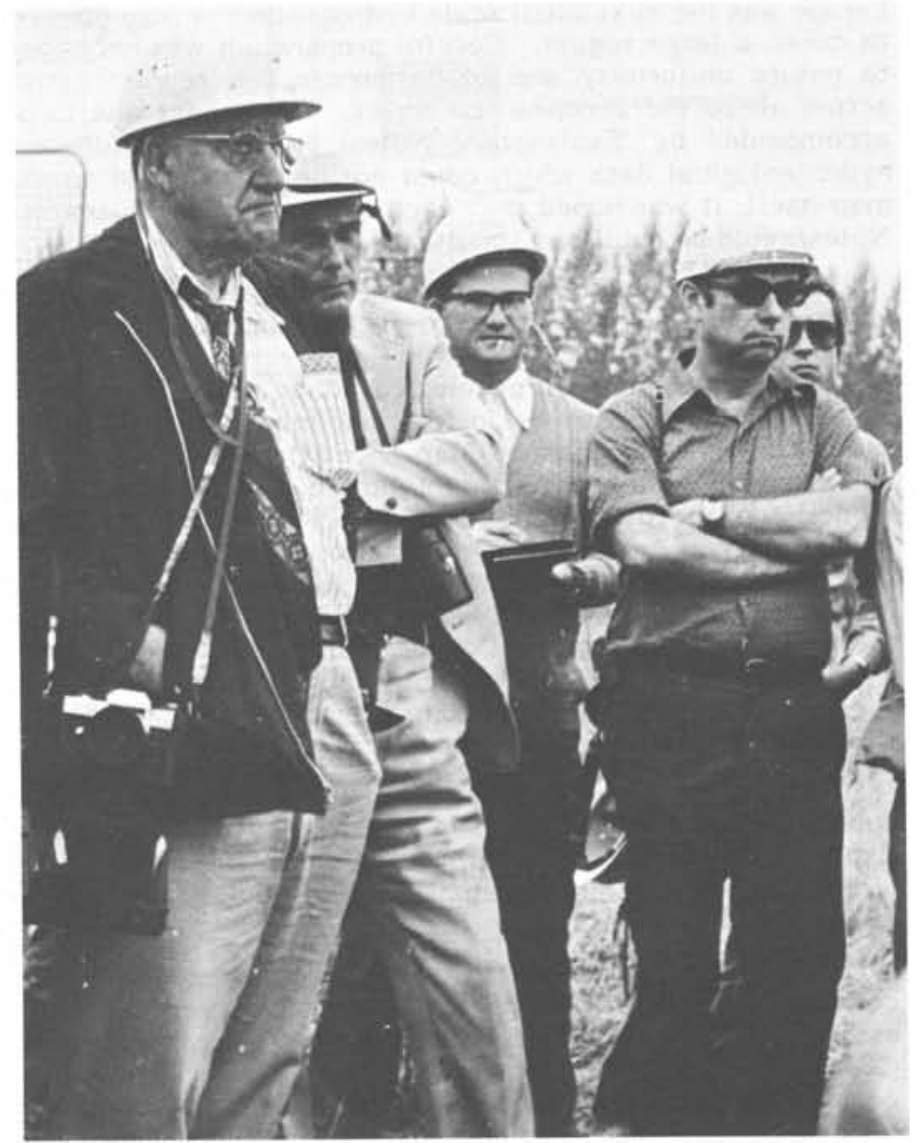

Attending the Fifth International Kaolin Symposium (left to right: Prof. W.D. Keller (U.S.A.), Prof. Harder (F.R.G.), Dr. Wiewiora (Poland), and Dr. M. Kuzvart (Czechoslovakia), the author.

ABOUT THE AUTHOR: Milos Kuzvart, Secretary of IGCP Project 23 - "Genesis of kaolins", is with the Institute of Geological Sciences, Charles University in Prague, Czechoslovakia. His article is a condensed and up-dated version of a paper he presented at the Eighth International Kaolin Symposium held in Madrid in 1977. 